\title{
Computer optimization methods of decision processes in a manufacturing company
}

\author{
Komputerowe metody optymalizacji procesów decyzyjnych \\ w przedsiębiorstwie produkcyjnym
}

\author{
AGNIESZKA MAZUR-DUDZIŃSKA \\ JACEK DUDZIŃSKI *
}

DOI: https://doi.org/10.17814/mechanik.2017.7.65
The paper aims to describe the linear programming model and to sample the application of the linear programming model to optimize the production volume in a small company from the armaments industry. Using the methods and tools of operational research in engineering and managerial practice can effectively help, greatly facilitate and accelerate decision making.

KEYWORDS: operation research, optimization models, linear programming, computer techniques of optimization

Making business decisions is a complex process that requires careful analysis of the situation, setting the criteria for choosing a solution, and finding optimum solutions. This process includes the following steps [1, 2]:

- formulation of a decision problem, i.e. description of the decision situation;

- construction of a mathematical model of this decisionmaking situation;

- selection of the appropriate algorithm to determine the optimal solution and solve the task;

- analysis of the task sensitivity of optimization solutions;

- model verification;

- implementation of the solution.

The paper describes the linear programming model and discusses the use of this model in a manufacturing company. As an example, a linear programming model was developed to determine the optimum production structure in a small manufacturing company in the armaments industry and then solved this decision problem using Solver in Excel spreadsheet.

\section{Linear programming model}

The simplest decision models are static linear models with one decision selection criterion. Linear programming is the most widely used method of finding the optimal solution for this type of model. This method is used e.g. to determine the optimal (from the point of view of maximizing profit or minimizing costs) production structure with limited resources means of production. This problem can be written in the form of a mathematical model, including the objective function (1), constraint conditions (2), and boundary conditions (3):

\footnotetext{
* Dr Agnieszka Mazur-Dudzińska (biuro@ppm-vega.com) - Przedsiębiorstwo Projektowo-Marketingowe Vega; dr inż. Jacek Dudzińsk (jacek.dudzinski@wat.edu.pl) - Wydział Mechatroniki i Lotnictwa Wojskowej Akademii Technicznej
}

$\begin{array}{lll}\mathbf{c}^{\mathrm{T}} \mathbf{x} \rightarrow \max & \text { or } & \mathbf{c}^{\mathrm{T}} \mathbf{x} \rightarrow \min \\ \mathbf{A x} \leq \mathbf{b} & \text { or } & \mathbf{A x} \geq \mathbf{b} \\ \mathbf{x} \geq \mathbf{0} & \text { or } & \mathbf{x} \geq \mathbf{0}\end{array}$

where:

$\mathbf{x}^{\mathrm{T}}=\left[\begin{array}{llll}x_{1} & x_{2} & \ldots & x_{n}\end{array}\right] \quad-$

vector of decision variables (e.g. production volume of the $j$-th product);

$\mathbf{c}^{\mathrm{T}}=\left[\begin{array}{llll}c_{1} & c_{2} & \ldots & c_{n}\end{array}\right]-$ purpose function vector (e.g. $c_{j}$ - unit profit obtained on the $j$-th product in the models maximizing the criterion function or unit cost incurred for the production of the $j$-th product in the models minimizing the function of the criterion);

$\left.\mathbf{A}=\left[\begin{array}{ccc}a_{11} & \ldots & a_{1 n} \\ \ldots & \ldots & \ldots \\ a_{m 1} & \ldots & a_{m n}\end{array}\right] \quad \begin{array}{l}\text { matrix of parameters }(\mathrm{e} . \mathrm{g} . \\ \end{array}\right] \begin{aligned} & a_{i j}-\text { consumption of } i \text {-th } \\ & \text { per uniterial }(i=1, \ldots, m) \\ & 1, \ldots, n)) ;\end{aligned}$

$\mathbf{b}^{\mathrm{T}}=\left[\begin{array}{llll}b_{1} & b_{2} & \ldots & b_{m}\end{array}\right] \quad-\quad$ vector of constraints (e.g. $b_{i}$ - resource of $i$-th raw material).

In case where decision variables must take integer or binary values, boundary conditions (3) add additional conditions $\left(x_{j} \in \mathrm{C}\right.$ or $\left.x_{j} \in\{0 ; 1\}\right)$.

When building a mathematical model, decision variables must be at first precisely determined, because they identify specific decisions. Boundary conditions determine the range of values that decision variables can take. The purpose function describes the decisionmaking criterion, while limiting conditions describe certain limitations that must be considered in the search for a solution.

Searching for a solution to a linear programming task consists in determining in the first step the so called a set of permissible solutions, that is, the set of values of decision variables satisfying the constraints and boundary conditions, and then - finding such a 
permissible solution that ensures the optimal value of the purpose function.

The simplex method [4] is the universal and most widely used method for solving linear programming tasks with arbitrary number of decision variables. Simplex algorithm is an iterative method and is based on the study of new solutions base (permissible solutions) in such a way that [5]:

- there is (any) basic solution,

- it is checked if the solution is optimal,

- if the current solution is not optimal, another base solution is built (better or at least not worse than the previous one).

The procedure is repeated until an optimal solution is found, which can no longer be improved. Simplex method often requires a large number of iterations, so it is quite laborious, therefore appropriate computer programs are helpful to use it in practice.

\section{Example of linear programming application}

An example optimization model is for a small manufacturing company that produces three types of combustible covers (caliber 60, caliber 98, caliber 120) and combustible cardboard. The decision problem is defined as the search for the quantity of products (produced within a month) optimized for maximizing the company's revenue, assuming: limited resources, limited machine hours and people and the required order size. Essential information obtained from the company concerning the unit consumption of raw materials and the working time of machines and people needed to produce units of individual products - is summarized in table I.

TABLE I. Unit consumption of raw materials and unit operating time of machines and people

\begin{tabular}{|l|c|c|c|c|}
\cline { 2 - 5 } \multicolumn{1}{c|}{} & \multicolumn{3}{|c|}{ Combustible cover } & Combustible \\
\cline { 2 - 5 } & $\begin{array}{c}\text { Caliber 60, } \\
\text { thousand } \\
\text { pcs. }\end{array}$ & $\begin{array}{c}\text { Caliber 98, } \\
\text { thousand } \\
\text { pcs. }\end{array}$ & $\begin{array}{c}\text { Caliber 120, } \\
\text { thousand } \\
\text { pcs. }\end{array}$ & $\begin{array}{c}\text { cardboard, } \\
\text { thousand } \\
\text { pcs. }\end{array}$ \\
\hline $\begin{array}{l}\text { Machine working } \\
\text { Mame, } h\end{array}$ & 67 & 67 & 34 & 67 \\
\hline $\begin{array}{l}\text { Employee work- } \\
\text { ing time (work } \\
\text { hours) }\end{array}$ & 77 & 77 & 44 & 67 \\
\hline
\end{tabular}

It is also known that: monthly resource of raw materials is $300 \mathrm{~kg}$, machines can work up to 660 hours a month, and people - 540 hours (the company employs three people who work 180 hours a month). Due to signed contracts, the plant must produce at least 1,500 combustible covers caliber 60 and at least 1,000 combustible covers caliber 98 . The price per 1,000 of each of the products is 16,000 PLN for combustible covers caliber 60, 27,000 PLN for combustible covers caliber 98, 46,000 PLN for combustible covers caliber 120 and 95,000 PLN for combustible cardboards.

The decision problem can be written as a mathematical model. The decision variables are: $x_{1}$ production volume (per month) of combustible covers caliber 60 (in thousands), $x_{2}$ - production volume (per month) of combustible covers caliber 98 (in thousands), $x_{3}$ - production volume (per month) of combustible covers (per month) caliber 120 (in thousands), $x_{4}$ monthly production of combustible cardboards (in thousands). Each decision variable must accept nonnegative values, which describe the boundary conditions of the form: $x_{1} \geq 0 ; x_{2} \geq 0 ; x_{3} \geq 0 ; x_{4} \geq 0$. Assumptions regarding the consumption and basic resources of raw materials, working time of machines and production workers, and production requirements of some products create conditions limiting the linear programming tasks and are written in the form of the following inequalities:

- $2 x_{1}+13 x_{2}+9 x_{3}+80 x_{4} \leq 300 \mathrm{~kg}-$ condition related to the raw material,

- $67 x_{1}+67 x_{2}+34 x_{3}+67 x_{4} \leq 660 \mathrm{~h}-$ condition related to machine working time,

- $77 x_{1}+77 x_{2}+44 x_{3}+67 x_{4} \leq 540$ work hours - condition related to employee working time,

$-x_{1} \geq 1.5$ thousand pcs. - condition related to the minimum quantity of product $x_{1}$,

$-x_{2} \geq 1$ thousand pcs. - condition related to minimum quantity of product $x_{2}$.

The goal of the company is to achieve the highest possible sales revenue, which is written as the purpose function:

$$
f(x)=16 x_{1}+27 x_{2}+46 x_{3}+95 x_{4} \rightarrow \max
$$

To solve such linear programming task using computer, the mathematical model should be entered in the appropriate (tabular) way in the Excel spreadsheet. The purpose function and the left side of the constraint conditions are written to the appropriate cells of the spreadsheet using formulas referencing the cell addresses containing the data (table II).

After entering the data into the spreadsheet, select the solver tool from the menu and in the corresponding window cells that appear, enter the job parameters, i.e. the cell address in which the formula for the target function is located, the cell address values of the decision variables, and the constraint and boundary conditions. (fig. 1). It should be remembered that in the "options", tab indicates that the model is linear.

Once you have correctly entered the parameters of a linear programming task, you can go to the solution that is generated as the results report - at this stage in the data sheet, in the decision variable value cells and in the target function, the optimal values appear; you can also read the result of the entered formulas for the left side of the constraint conditions (figs. 2-4).

As can be seen in fig. 2 and in the results report in fig. 3 , the optimal values of the decision variables are: $x_{1}$ $=1.5$ thousand pcs; $x_{2}=1$ thousand pcs., $x_{3}=3.007$ thousand pcs., $x_{4}=3.312$ thousand pc The optimal value of the purpose function is 494.442 thousand PLN. The largest monthly revenue (which will amount to 494.442 thousand PLN) will thus reach a monthly production of 1.5 thousand pcs. of combustible covers caliber $60 ; 1$ thousand pcs. of combustible covers caliber 98; 3.007 thousand pcs. of combustible covers caliber 120 and 3.212 thousand pcs. of combustible cardboards. From the table on the conditions for limiting the results report (fig. 3), one can read which constraints are binding, that is, the bottleneck of the production process. It turns out that only a working time machine has not been fully exploited (the information in the column "backlash" that the machine could still work 175 hours). The size of production is determined by the resource stock and the working time of people - these factors are the bottleneck.

The assumptions for the minimum volume of production of combustible covers caliber 60 and combustible covers caliber 98 are also important. It can be assumed that increasing the stock of raw material or the number of man-hours will increase the volume of production and consequently the monthly revenue of the company. 
TABLE II. Data spreadsheet

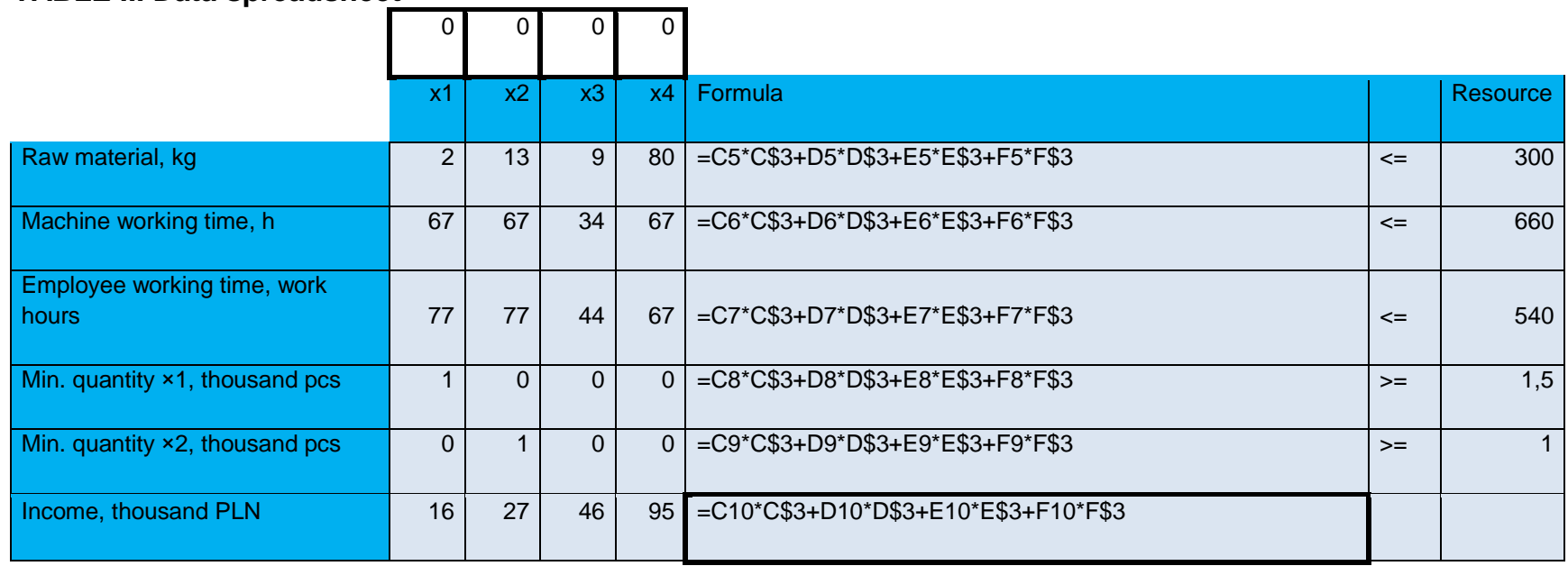

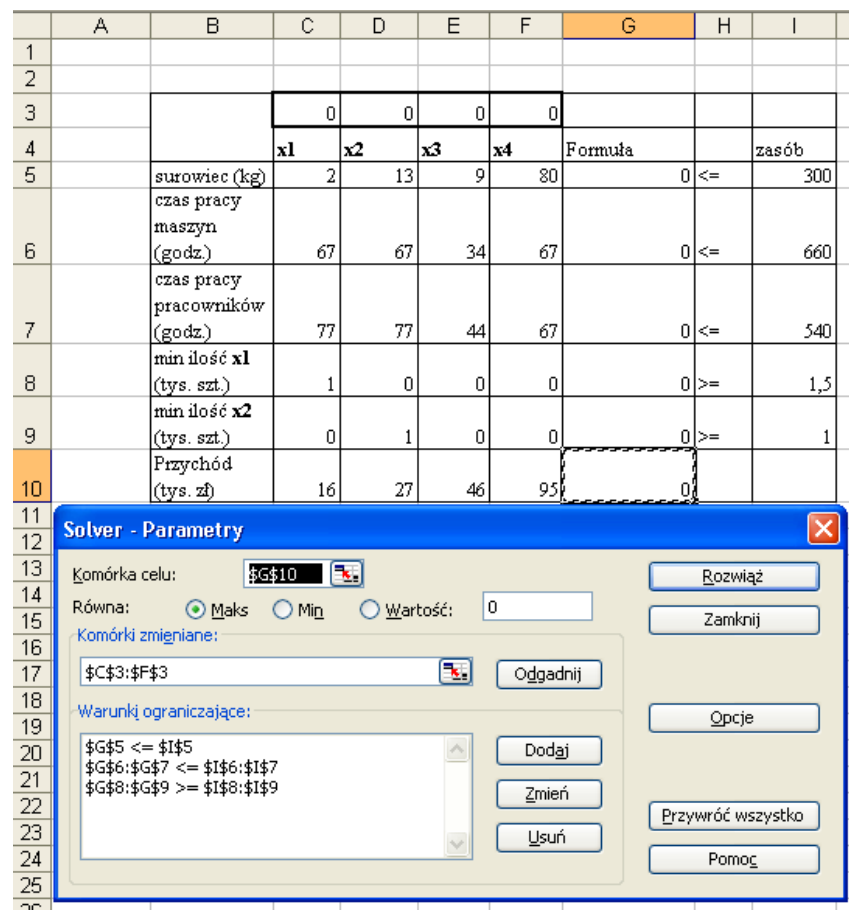

Fig. 1. Data sheet and solver window

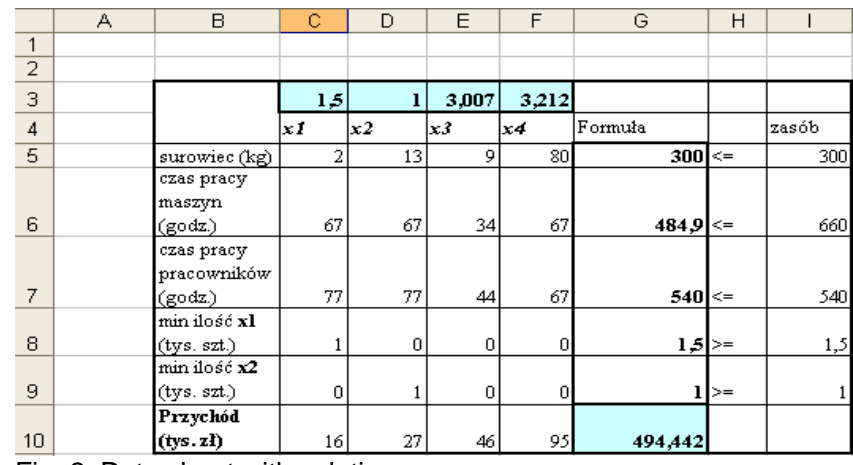

Fig. 2. Data sheet with solution

The answer to the question of how much increase in the amount of raw material or the increase in the working time of people affects the company's revenue growth can be found in the sensitivity report (fig. 4) - it is enough to read the value of the dual price for these means of production. The dual price for the raw material is 0.376 thousand PLN/kg, which means that if the stock of this raw material is increased by $1 \mathrm{~kg}$, the monthly revenue of the company (the value of the function of the target) will increase by $376 \mathrm{PLN}$. On the other hand, the price for employee working hours is $0.968 \mathrm{PLN}$, suggesting that the increase in employee working hours per month by 1 man-hour will increase the company's monthly income by 968 PLN. Apart from the dual price values, postoptimization analysis is included in the sensitivity report.

Microsoft Excel 11.0 Raport wyników

Komórka celu (Maks)

\begin{tabular}{|c|c|c|c|}
\hline Komórka & Nazwa & Wartość pocz. & Wartość końcowa \\
\hline$\$ G \$ 10$ & Przychód (tys. zł) & 0 & 494,442 \\
\hline \multicolumn{4}{|c|}{ Komórki decyzyjne } \\
\hline Komórka & Nazwa & Wartość pocz. & Wartość końcowa \\
\hline$\$ C \$ 3$ & wartość x1 & 0 & 1,5 \\
\hline$\$ D \$ 3$ & wartość x2 & 0 & 1 \\
\hline \$E $\$ 3$ & wartość $\times 3$ & 0 & 3,007 \\
\hline$\$ F \$ 3$ & wartość $\times 4$ & 0 & 3,212 \\
\hline
\end{tabular}

\begin{tabular}{|c|c|c|c|c|}
\hline Komórka & Nazwa & formuła & Status & 147 \\
\hline$\$ G \$ 5$ & surowiec $(\mathrm{kg})$ & $300 \$ G \$ 5<=\$ 1 \$ 5$ & Wiażace & 0 \\
\hline SG $\$ 6$ & czas pr. maszyn (godz.) & 484.9 SG $\$ 6<=\$ 1 \$ 6$ & Nie wiążace & 175,1 \\
\hline$\$ G \$ 7$ & czas pr. ludzi (godz.) & $540 \$ G \$ 7<=\$ 1 \$ 7$ & Wiażace & 0 \\
\hline$\$ G \$ 8$ & min ilość x1 (tys. szt.) & $1,5 \$ G \$ 8>=\$ 1 \$ 8$ & Wiażace & 0 \\
\hline SG99 & min ilość $\times 2$ (tys. szt.) & $1 \$ G \$ 9>=\$ 1 \$ 9$ & Wiażace & 0 \\
\hline
\end{tabular}

Fig. 3. Results report

Microsoft Excel 11.0 Raport wrażliwości

Komórki decyzyjne

\begin{tabular}{|c|c|c|c|c|c|c|}
\hline \multirow[b]{2}{*}{ Komórka } & \multirow[b]{2}{*}{ Hazwa } & \multirow{2}{*}{$\begin{array}{l}\text { Wartość } \\
\text { końcowa }\end{array}$} & \multirow{2}{*}{$\begin{array}{l}\text { Przyrost } \\
\text { krańcowy }\end{array}$} & \multicolumn{3}{|c|}{ Wspótczynnik Dopuszczalny Dopuszczalmy } \\
\hline & & & & funkcji celu & wzrost & spadek \\
\hline$\$ \subset \$ 3$ & $\times 1$ & 1,5 & 0 & 16 & 59,324 & $1 E+30$ \\
\hline$\$ D \$ 3$ & $\times 2$ & 1 & 0 & 27 & 52,465 & $1 E+30$ \\
\hline \$E\$3 & $\times 3$ & 3,007 & 0 & 46 & 16,388 & 28,717 \\
\hline \$F\$3 & $\times 4$ & 3,212 & 0 & 95 & 286,031 & 24,955 \\
\hline \multicolumn{7}{|c|}{ Warunki ograniczające } \\
\hline & & Wartość & Cena & Prawa strona & lopuszczalny t & Jopuszczalny \\
\hline Komórka & Hazwa & końcowa & dualna & w. o. & wzrost & spadek \\
\hline$\$ \in \$ 5$ & surowiec $(\mathrm{kg})$ & 300 & 0,376 & 300 & 130,9 & 212,9 \\
\hline$\$ Q \$ 6$ & czas pr. maszyn (godz.) & 484,9 & 0 & 660 & $1 \mathrm{E}+30$ & 175,1 \\
\hline$\$ \in \$ 7$ & czas pr. ludzi (godz.) & 540 & 0,968 & 540 & 241,2 & 109,7 \\
\hline$\$ \in \$ 8$ & min ilość x1 (tys. szt.) & 1,5 & $-59,324$ & 1,5 & 1,456 & 1,5 \\
\hline$\$ Q \$ 9$ & min ilość $\times 2$ (tys. szt.) & 1 & $-52,465$ & 1 & 1,659 & 1 \\
\hline
\end{tabular}

Fig. 4. Sensitivity report

\section{Conclusions}

Using methods and tools of operational research in engineering and managerial practice can greatly facilitate and accelerate decision-making process. The availability of relatively inexpensive computer tools makes it unfeasible to use complex methods and algorithms. The advantage of using computer packages for decision optimization is also the speed of getting a solution. However, it must be remembered that in order to receive a correct solution to the decision problem, it is necessary 
first of all to properly build a decision model. Decision makers include: the choice and precise definition of decision variables, the selection of model parameters, the correct formulation of the objective function and constraining conditions (taking into account all relevant factors and assumptions) and verification of the solution obtained.

\section{REFERENCES}

1. Witkowska D. "Metody wspomagajace podejmowanie decyzji w zarządzaniu”. Łódź: Firma Księgarsko-Wydawnicza „Menadżer”, 2000.

2. Sikora W. (ed.). „Badania operacyjne”. Warszawa: Polskie Wydawnictwo Ekonomiczne, 2008.

3. Woleński J., Urich R. „Badania operacyjne w praktyce menedżera. Wybrane problemy i przykłady zastosowań". Warszawa: Oficyna Wydawnicza Warszawskiej Szkoły Zarządzania, 2004.

4. Łapińska-Sobczak N. (ed.). „Modele optymalizacyjne. Przykłady $i$ zadania”. Łódź: Wydawnictwo Uniwersytetu Łódzkiego, 1998.

5. Jędrzejczyk Z., Skrzypek J., Kukuła K. (ed.), Walkosz A. „Badania operacyjne w przykładach i zadaniach". Warszawa: Wydawnictwo Naukowe PWN, 1999. 